ISSN 0258-7122

Bangladesh J. Agril. Res. 38(1): 19-28, March 2013

\title{
DEVELOPMENT OF INSECTICIDE APPLICATION SCHEDULE FOR MANAGEMENT OF FLOWER THRIPS AND POD BORER IN MUNGBEAN (Vigna radiata L.)
}

\author{
MD. Altaf Hossain ${ }^{1}$
}

\begin{abstract}
The experiments were conducted to develop insecticide (Imidachlorpid, Imitaf 20SL at $0.5 \mathrm{ml} / \mathrm{l}$ ) application schedule for the effective management of thrips and pod borer attacking mungbean during kharif-I season of 2010 and 2011. In both the years, suppression of thrips population and pod borer infestation were higher in double sprayed treatment than single spraying. Single spraying at 35 DAS (100\% flowering) and 42 DAS (100\% podding stage) suppressed flower infestation by thrips upto 86 and 93\%, respectively, during 2010 and 100 \& $96 \%$, respectively, during 2011. Double spraying at 42 DAS (100\% podding) and 49 DAS (seed developing stage) reduced more pod borer infestation as much as $81-83 \%$. In kharif-I 2010, significantly the highest yield (1798 kg/ha) and MBCR (4.67) were obtained from the plots sprayed twice with Imidachlorpid at 42 DAS (100\% podding) and 49 DAS (seed developing stage) but in kharif-I 2011, significantly the highest yield (1457 kg/ha) and MBCR (5.75) were obtained from the plots sprayed twice with Imidachlorpid at 35 DAS (100\% flowering) and 42 DAS (100\% podding stage). The double spray schedule appeared to be more effective than single spraying against pod borer. But single spray at 42 DAS (100\% podding stage) appeared as more effective against flower thrips.
\end{abstract}

Keywords: Insecticide application schedule, thrips, pod borer, management, mungbean.

\section{Introduction}

Mungbean (Vigna radiata L.) is one of the important pulse crops in Bangladesh. Farmers become more interested to cultivate this short duration valuable pulse crop after harvesting of rabi crops (kharif-I season). More than twelve species of insect pests were found to infest mungbean in the field in Bangladesh (Rahman et al. 2000). Among them, thrips and pod borers are the major insect pests causing considerable losses (Rahman et al., 1981; Bakr 1998; Rahman et al., 2000; Hossain et al., 2004). Thrips is associated mostly with the damage of tender buds and flowers of mungbean. Extensive damage of thrips to summer mungbean (kharif-I season) resulted flower shedding and significant yield loss (Chhabra and Kooner 1985; Lal 1985). Pod borer damages flowers, flower buds along with developing or mature pods (Poehlman 1991). Pod borer alone has been reported

${ }^{1}$ Principal Scientific Officer, Regional Agricultural Research Station, Bangladesh Agricultural Research Institute (BARI), Ishurdi 6620, Pabna, Bangladesh. 
to cause grain yield loss of $136 \mathrm{~kg} / \mathrm{ha}$ (Anon., 1986). Chemical insecticides are generally used to control thrips and pod borers attacking mungbean. Generally farmers spray insecticides to manage these insects when flower dropping starts due to thrips or pod boring by the visible full grown borers at pod maturing stage. As a result, thrips and the grown up pod borers are not killed properly, instead it creates environmental pollution, health hazards and economic loss. To overcome the misuse of insecticides and environmental hazard, there is a necessity to develop an effective and economic insecticide application schedule for the protection of mungbean against thrips and pod borers attack. Until now sufficient information on the development of effective and economic spray schedule for the management of thrips and pod borer in mungbean are not available. The present study was undertaken to develop an insecticide (Imidachlorpid, Imitaf 20SL) application schedule for the effective and economic management of thrips and pod borer attacking mungbean and to ensure economic production.

\section{Materials and Method}

The experiments were conducted at Pulses Research Center, Ishurdi, Pabna, Bangladesh during kharif-I, 2010 and 2011. There were 6 treatments of Imidachlorpid (Imitaf 20SL) spraying at $0.5 \mathrm{ml} / \mathrm{l}$ at different growth stages of mungbean viz., 1. Spraying at 35 DAS (at 100\% flowering stage), 2. Spraying at 42 DAS (100\% podding stage), 3. Spraying at 49 DAS (at seed developing stage), 4. Spraying at $(35+42)$ DAS (at $100 \%$ flowering and $100 \%$ podding stage), 5. Spraying at (42 and 49) DAS (100\% podding and seed developing stage) and 6. Untreated control. The experiments were laid out in RCB design with three replicates. The treatment was randomly distributed in each replicate. The unit plot size was $3 \mathrm{~m} \times 4 \mathrm{~m}$ with a distance of $100 \mathrm{~cm}$ between the plots and $150 \mathrm{~cm}$ between the replicates. The seeds of BARImung- 6 were sown in March 25, 2010 and March 20, 2011 in rows with the spacing of $30 \mathrm{~cm}$. The BARImung-6 is the most popular short duration variety which covers majority of the areas in Bangladesh. It initiates flowering at 30 days after sowing (DAS) and $100 \%$ flowering at 35 DAS, $100 \%$ podding at 42 DAS, seed developing at 49 DAS and ripening at 55 DAS. The populations of the plant were maintained constant by keeping plant to plant distance of 7 cm. NPK fertilizers @ 20-40-20 $\mathrm{kg} / \mathrm{ha}$ in the form of urea, triple super phosphate and muriate of potash were applied during final land preparation. Imidachlorpid (Imitaf 20SL) was sprayed at $0.5 \mathrm{ml} /$ litre according to the growth stages as described under five treatments. Normal intercultural operations were done.

The data on the population of thrips (Megalurothrips distalis) were collected before and after 24 hours of each spraying. Thrips population was assessed from 20 opened flowers randomly collected from both side of two rows in each plot avoiding border rows and central four rows. The collected flowers were immediately opened on the white paper board and counted the thrips. Central four rows were kept undisturbed for recording yield data. 
At maturity, all the pods were collected from 10 randomly selected plants from central four rows of each plot and examined. The infested (bored) and total numbers of pods were counted and the per cent pod infestation was determined using the following formula:

$\%$ Pod infestation $=\frac{\text { Number of infested pods }}{\text { Total number of pods }} \times 100$

I' lhe pods of central four rows of each plot comprising $4.8 \mathrm{~m}^{2}(1.2 \mathrm{~m} \mathrm{x} 4 \mathrm{~m})$ area were harvested. The pods were then threshed, grains were cleaned and dried in the bright sunshine. The grain yield obtained from each plot was converted into per hectare.

The experimental data were analyzed by MSTAT-C software. The per cent data were transformed by square root transformation for statistical analysis. Treatment mean were compared using Duncan's Multiple Range Test .

The marginal benefit cost ratio (MBCR) was calculated on the basis of prevailing market price of mungbean, Imidachloprid and spraying cost. Marginal benefit cost ratio was calculated as follows:

$$
\text { MBCR }=\frac{\text { Benefit over control }}{\text { Cost of treatment }}
$$

\section{Results and Discussion}

\section{Effect of Imidachloprid application on flower infestation}

Imidachloprid application at different growth stages of mungbean suppressed flower infestation and thrips population significantly in both the years presented in Table 1 and 2. It was observed that both the nymphs and adults of thrips attacked the mungbean flowers by entering them. Some of them moved outside the flowers to ensure their presence and causing damage. After flower infestation the thrips populations increased significantly until seed developing stage of mungbean with more one thrips per flower damaging almost average one flower. Both the single and double spraying of Imidachloprid starting from flowering to seed developing stage significantly reduced flower infestation and thrips population. Hossain et al. (2004) reported that double spraying reduced more flower thrips in mungbean than single one. Between two double sprayed treatments, spraying at 35 DAS (100\% flowering) + 42 DAS (100\% podding) reduced more flower infestation and suppressed more thrips population than spraying at 42 DAS (100\% podding) and 49 DAS (seed developing stage). After 24 hrs of spray application, reduction of flower infestation and thrips population was more than $80 \%$ in all the treatments in both the seasons. Imidachloprid showed significant performance in reducing flower infestation and thrips population reduction. 
Table 1. Imidachloprid application at different growth stages on the incidence thrips population and flower infestation in $\mathbb{N}$ mungbean during Kharif-1 2010.

\begin{tabular}{|c|c|c|c|c|c|c|}
\hline \multirow[t]{2}{*}{ Treatments } & \multicolumn{2}{|c|}{$\begin{array}{c}\text { No. of infested flowers/20 } \\
\text { open flowers }\end{array}$} & \multicolumn{2}{|c|}{ No. of thrips/ 20 open flowers } & \multirow{2}{*}{$\begin{array}{l}\text { Percent reduction } \\
\text { of infested flower } \\
\text { after } 24 \text { hrs of } \\
\text { spray }\end{array}$} & \multirow{2}{*}{$\begin{array}{c}\text { Percent reduction } \\
\text { of thrips } \\
\text { population after } \\
24 \text { hrs of spray }\end{array}$} \\
\hline & Before spray & $\begin{array}{l}\text { After } 24 \text { hrs } \\
\text { of spray }\end{array}$ & Before spray & $\begin{array}{l}\text { After } 24 \text { hrs } \\
\text { of spray }\end{array}$ & & \\
\hline $\begin{array}{l}\text { Spraying at } 100 \% \text { flowering stage } \\
\text { (35 DAS) }\end{array}$ & $6.67 c$ & 1.00 & $7.67 \mathrm{c}$ & 1.00 & 85.01 & 86.35 \\
\hline $\begin{array}{l}\text { Spraying at } 100 \% \text { podding stage ( } 42 \\
\text { DAS) }\end{array}$ & $13.33 \mathrm{~b}$ & 1.00 & $13.67 \mathrm{~b}$ & 1.00 & 92.50 & 92.52 \\
\hline $\begin{array}{l}\text { Spraying at seed developing stage } \\
\text { (49 DAS) }\end{array}$ & 16.67 a & 1.33 & 33.33 a & 1.33 & 92.02 & 96.29 \\
\hline $\begin{array}{l}\text { Spraying at } 100 \% \text { flowering }+100 \% \\
\text { podding stage }(35+42) \text { DAS }\end{array}$ & $5.83 \mathrm{c}$ & 1.00 & $6.67 \mathrm{c}$ & 1.00 & 82.82 & 83.33 \\
\hline $\begin{array}{l}\text { Spraying at } 100 \% \text { podding }+ \text { seed } \\
\text { developing stage }(42+49) \text { DAS }\end{array}$ & $12.67 \mathrm{~b}$ & 1.50 & $14.17 \mathrm{~b}$ & 1.50 & 88.16 & 89.03 \\
\hline Untreated control & $17.33 \mathrm{a}$ & 16.67 & 33.67 a & 32.33 & 3.81 & 3.98 \\
\hline
\end{tabular}

In a column, treatment means having the same letter are not significantly different at $5 \%$ level. 
Table 2. Imidachloprid application at different growth stages on the incidence thrips population and flower infestation in mungbean during kharif-1 2011.

\begin{tabular}{|c|c|c|c|c|c|c|}
\hline \multirow{2}{*}{ Treatments } & \multicolumn{2}{|c|}{$\begin{array}{l}\text { No. of infested flowers/20 } \\
\text { open flowers }\end{array}$} & \multicolumn{2}{|c|}{ No. of thrips/ 20 open flowers } & \multirow{2}{*}{$\begin{array}{l}\text { Percent reduction } \\
\text { of infested flower } \\
\text { after } 24 \text { hrs of } \\
\text { spray }\end{array}$} & \multirow{2}{*}{$\begin{array}{l}\text { Percent reduction } \\
\text { of thrips } \\
\text { population after } \\
24 \text { hrs of spray }\end{array}$} \\
\hline & Before spray & $\begin{array}{c}\text { After } 24 \text { hrs } \\
\text { of spray }\end{array}$ & Before spray & $\begin{array}{c}\text { After } 24 \text { hrs } \\
\text { of spray }\end{array}$ & & \\
\hline $\begin{array}{l}\text { Spraying at } 100 \% \text { flowering stage } \\
\text { (35 DAS) }\end{array}$ & $6.67 \mathrm{~b}$ & 0.00 & $7.67 \mathrm{~b}$ & 0.00 & 100 & 100 \\
\hline $\begin{array}{l}\text { Spraying at } 100 \% \text { podding stage ( } 42 \\
\text { DAS) }\end{array}$ & $15.67 \mathrm{a}$ & 0.67 & $25.00 \mathrm{a}$ & 0.67 & 95.72 & 97.32 \\
\hline $\begin{array}{l}\text { Spraying at seed developing stage } \\
\text { (49 DAS) }\end{array}$ & $13.67 \mathrm{a}$ & 1.67 & $22.33 \mathrm{a}$ & 1.67 & 87.78 & 92.52 \\
\hline $\begin{array}{l}\text { Spraying at } 100 \% \text { flowering }+100 \% \\
\text { podding stage }(35+42) \text { DAS }\end{array}$ & $8.67 \mathrm{~b}$ & 1.33 & $12.00 \mathrm{~b}$ & 1.33 & 84.66 & 88.92 \\
\hline $\begin{array}{l}\text { Spraying at } 100 \% \text { podding }+ \text { seed } \\
\text { developing stage }(42+49) \text { DAS }\end{array}$ & 14.33 a & 2.00 & $25.00 \mathrm{a}$ & 2.00 & 86.04 & 92.00 \\
\hline Untreated control & $15.67 \mathrm{a}$ & 15.33 & $25.33 \mathrm{a}$ & 24.67 & 2.17 & 2.61 \\
\hline
\end{tabular}

In a column, treatment means having the same letter are not significantly different at $5 \%$ level. 


\section{Effect of Imidachloprid application on pod infestation}

The larvae of pod borer consumed seed of mungbean when the pod developed and a single borer damaged more than one pods as voracious feeder. The damaged pods showed hole and reduced yield. Imidachloprid application significantly reduced pod borer infestation in both the years (Table 3).

During kharif-I 2010, the lowest pod borer infestation (2.02\%) was observed in double spraying at 42 DAS (100\% podding) and 49 DAS (seed developing stage) which was statistically identical to double spraying at 35 DAS (100\% flowering) and 42 DAS (100\% podding). Among the single sprayed treatments, spraying at 49 DAS (seed developing stage) received the lowest pod infestation (4.11\%) which was statistically identical to 42 DAS (100\% podding) and followed by 35 DAS (100\% flowering). Pod borer infestation reduction over untreated control in single sprayed treatments ranged from 41.81 to $60.95 \%$ and in double sprayed it was 74.89 to $81.25 \%$. It was seen that pod infestation reduction was higher in double sprayed treatments than single spraying.

During kharif-I, 2011 cropping season, the incidence of pod borer was very low. The pod borer infestation ranged from $0.42-1.33 \%$ in all treated plots and $2.47 \%$ in untreated control showing no significant differences (Table 3). But the double spraying reduced pod damage more than single spraying. Numerically pod borer infestation reduction over control ranged from 46.15 to $82.99 \%$. Hossain et al. (2004) also agreed with the present findings of the superiority double spraying in reduction of pod borer infestation than single one.

\section{Yield}

The yields of different spray scheduled treatments are presented in Table 3. The yield of mungbean differed significantly depending on the level of suppression of thrips population and pod borer infestation by spraying Imidachloprid at different growth stages. During kharif-I, 2010, significantly the highest yield (1798 kg/ha) was obtained from the plots sprayed twice with Imidachlorpid at 42 DAS (100\% podding) and 49 DAS (seed developing stage) which was statistically identical to double spraying at 35 DAS (100\% flowering) and 42 DAS (100\% podding stage). The lowest yield (1595 kg/ha) was recorded from untreated control plots. All the single sprayed treatments on 100\% flowering, 100\% podding and seed developing stages at 35, 42, and 49 DAS gave statistically identical and lower yield which was lower than double spraying. In the next year the yield was lower than that of the previous year. In double spraying plots the yield of mungbean was the highest $(1457 \mathrm{~kg} / \mathrm{ha})$ against the lower yield in the single treated plots (Table 3). In this year, the pod infestation was insignificant and had no significant effect on yield. 
Table 3. Imidachloprid (Imitaf 20 SL) application on pod infestation by pod borer and yield of mungbean during Kharif-I 2010 and kharif-I 2011.

\begin{tabular}{|c|c|c|c|c|c|c|}
\hline \multirow[t]{2}{*}{ Treatments } & \multicolumn{2}{|c|}{ Infested pod (\%) } & \multicolumn{2}{|c|}{$\begin{array}{c}\text { Reduction of infested pod } \\
\text { over control (\%) }\end{array}$} & \multicolumn{2}{|c|}{ Yield (kg/ha) } \\
\hline & Kharif I, 10 & Kharif I, 11 & Kharif I, 10 & Kharif I, 11 & Kharif I, 10 & Kharif I, 11 \\
\hline $\begin{array}{l}\text { Spraying at } 100 \% \text { flowering stage (35 } \\
\text { DAS) }\end{array}$ & $\begin{array}{l}6.41 \mathrm{~b} \\
(2.52)\end{array}$ & 1.33 & 41.51 & 46.15 & 1653 bc & $1257 \mathrm{~d}$ \\
\hline $\begin{array}{l}\text { Spraying at } 100 \% \text { podding stage ( } 42 \\
\text { DAS) }\end{array}$ & $\begin{array}{l}4.53 \mathrm{bc} \\
(2.12)\end{array}$ & 1.00 & 58.67 & 59.51 & 1688 bc & 1307 c \\
\hline $\begin{array}{l}\text { Spraying at seed developing stage ( } 49 \\
\text { DAS) }\end{array}$ & $\begin{array}{l}4.11 \mathrm{bc} \\
(2.02)\end{array}$ & 0.67 & 60.95 & 72.87 & 1680 bc & $1273 \mathrm{~cd}$ \\
\hline $\begin{array}{l}\text { Spraying at } 100 \% \text { flowering }+100 \% \\
\text { podding stage }(35+42) \text { DAS }\end{array}$ & $\begin{array}{c}2.62 \mathrm{~cd} \\
(1.60)\end{array}$ & 0.52 & 74.89 & 78.95 & $1756 \mathrm{ab}$ & 1457 a \\
\hline $\begin{array}{l}\text { Spraying at } 100 \% \text { podding }+ \text { seed } \\
\text { developing stage }(42+49) \text { DAS }\end{array}$ & $\begin{array}{l}2.02 \mathrm{~d} \\
(1.37)\end{array}$ & 0.42 & 81.25 & 82.99 & 1798 a & $1388 \mathrm{~b}$ \\
\hline Untreated control & $\begin{array}{c}10.96 \mathrm{a} \\
(3.30)\end{array}$ & 2.47 & - & - & 1595 c & 1193 e \\
\hline
\end{tabular}

In a column, treatment means having the same letter(s) are not significantly at $5 \%$ level.

Figures in the parentheses are the square root transformed mean values. 
Table 4. Net income and marginal benefit cost ratio (MBCR) of mungbean due to single and double spraying with Imidachloprid $\tilde{\sigma}$ during kharif-I 2010 and kharif-I 2011.

\begin{tabular}{|c|c|c|c|c|c|c|c|c|c|c|c|c|}
\hline \multirow[t]{2}{*}{ Treatments } & \multicolumn{2}{|c|}{ Yield (kg/ha) } & \multicolumn{2}{|c|}{$\begin{array}{c}\text { Increase yield over } \\
\text { control (kg/ha) }\end{array}$} & \multicolumn{2}{|c|}{$\begin{array}{l}\text { Additional return } \\
\text { over control } \\
\text { (Tk./ha) }\end{array}$} & \multicolumn{2}{|c|}{$\begin{array}{l}\text { Cost of insecticide } \\
\text { appl. (Tk./ha) }\end{array}$} & \multicolumn{2}{|c|}{ Net return (Tk./ha) } & \multicolumn{2}{|c|}{$\begin{array}{l}\text { Marginal benefit cost } \\
\text { ratio (MBCR) }\end{array}$} \\
\hline & Krf-I,10 & Krf-I,11 & Krf-I,10 & Krf-I,11 & Krf-I,10 & Krf-I,11 & Krf-I,10 & Krf-I,11 & Krf-I,10 & Krf-I,11 & Krf-I,10 & Krf-I,11 \\
\hline $\begin{array}{l}\text { Spraying at } \\
100 \% \text { flowering } \\
\text { stage (35 DAS) }\end{array}$ & 1653 bc & $1257 \mathrm{~d}$ & 58 & 64 & 3480 & 3520 & 1075 & 1075 & 2405 & 2445 & 2.24 & 2.27 \\
\hline $\begin{array}{l}\text { Spraying at } \\
100 \% \text { podding } \\
\text { stage (42 DAS) }\end{array}$ & 1688 bc & 1307 c & 93 & 114 & 5580 & 6270 & 1075 & 1075 & 4505 & 5195 & 4.19 & 4.83 \\
\hline $\begin{array}{l}\text { Spraying at seed } \\
\text { developing stage } \\
\text { (49 DAS) }\end{array}$ & $1680 \mathrm{bc}$ & $1273 \mathrm{~cd}$ & 85 & 80 & 5100 & 4400 & 1075 & 1075 & 4025 & 3325 & 3.74 & 3.09 \\
\hline $\begin{array}{l}\text { Spraying at } \\
100 \% \text { flowering } \\
+100 \% \text { podding } \\
\text { stage }(35+42) \\
\text { DAS }\end{array}$ & $1756 \mathrm{ab}$ & 1457 a & 161 & 264 & 9660 & 14520 & 2150 & 2150 & 7510 & 12370 & 3.49 & 5.75 \\
\hline $\begin{array}{l}\text { Spraying at } \\
100 \% \text { podding }+ \\
\text { seed developing } \\
\text { stage }(42+49) \\
\text { DAS }\end{array}$ & $1798 \mathrm{a}$ & $1388 \mathrm{~b}$ & 203 & 195 & 12180 & 10725 & 2150 & 2150 & 10030 & 8575 & 4.67 & 3.99 \\
\hline Untreated control & $1595 \mathrm{c}$ & 1193 e & - & - & - & - & - & - & & - & - & - \\
\hline
\end{tabular}

DAS = Days after sowing. For calculating income and benefit the following market prices were used:

Imidachlorpid (Imitaf 20 SL) = Tk. 270/100 ml and Mungbean = Tk. 60/kg (Kharif-I 2010 and Tk. 55/kg (Kharif-I 2011)

Labour wage for spraying insecticide $=$ Tk. 200/day/labourer (8 hours day) 


\section{Income and marginal benefit cost ratio}

Income and marginal benefit cost ratio are presented in Table 4. The net income and marginal benefit cost ratio varied depending on cost of insecticidal application and insect pest control particularly thrips and pod borer. During kharif-I 2010, the highest net income (Tk 10030/ha) was recorded from double spraying at 42 DAS (100\% podding) and 49 DAS (seed developing stage) followed by double spraying (Tk 7510/ha) at 35 DAS (100\% flowering) and 42 DAS (100\% podding stage). The highest monetary benefit (MBCR 4.67) was obtained from double spraying at 42 DAS (100\% podding) and 49 DAS (seed developing stage) which was close to single spraying (4.19) at 42 DAS (100\% podding stage).

During kharif-I 2011, the highest net income (Tk 12370/ha) was recorded from double spraying at 35 DAS (100\% flowering) and 42 DAS (100\% podding stage) and nearly the same net income at 42 DAS (100\% podding). Accordingly the highest monetary benefit (5.75) was found from double spraying at 35 DAS (100\% flowering) and 42 DAS (100\% podding stage) followed by single spraying (4.83) at 42 DAS (100\% podding).

From the above discussion, it was found that single spray of Imidachloprid (Imitaf 20SL) at $0.5 \mathrm{ml} / \mathrm{l}$ reduced flower infestation and thrips population and double spraying on pod borer infestation significantly. Double spraying had longer insecticidal action and was more effective than single spraying. Single spraying at 42 DAS (100\% podding) and double spraying at 42 DAS (100\% podding) and 49 DAS (seed developing stage) provided the highest yield and MBCR against pod borer infestation. For managing thrips and pod borer in mungbean field effectively and to get the highest yield and benefit the above spray schedule might be useful.

\section{References}

Anonymous. 1986. Annual report of pulse improvement programme. 1985-86. Bangladesh Agricultural Research Institute (BARI), Joydebpur, Gazipur, Bangladesh.

Chhabra K.S. and B.S. Kooner. 1985. Loss of summer mungbean due to insect pests in Punjub. Indian J. Entomol. 47(1):103-105.

Hossain M.A., J. Ferdous, M.A. Sarkar and M.A.. Rahman. 2004. Insecticidal management of thrips and pod borers in mungbean. Bangladesh J. Agril. Res. 29(3): 347-356.

Lal, S.S. 1985. A review of insect pests of mungbean and their control on India. Trop. Pest Management 31(2): 105-114.

Poehlman, J. M. 1991. The Mungbean. Oxford and IBH Publ. Co. Pvt. Ltd., New Delhi, Bombay and Calcutta, 292 p. 
Rahman, M.M., M.A. Mannan and M.A. Islam. 1981. Pest survey of major summer and winter pulses in Bangladesh. In the proceedings of the National Workshop on Pulses. (eds.) A.K. Kaul, Pp. 265-273.

Rahman, M.M., M.A Bakr, M.F. Mia, K.M. Idris, C.L.L. Gowda, J. Kumar, U.K. Dev, M.A. Malek, and A. Sobhan. 2000. Legumes in Bangladesh in Johansen, C., Duxbury, J.M., Virmani, S.M., Gowda, C.L.L., Pande, S. and Joshi, P.K. (eds.) 2000. In Legumes in rice and wheat cropping systems of the Indo-Gangetic Plain Constraints and opportunities. Patancheru 502 324, Andhra Pradesh, India: ICRISAT and Ithaca, New York, USA: Cornell University. 230 pp. ISBN 92-9066-428-5. 